\title{
Lời mời đóng góp bài Chuyên đề Tài chính khởi nghiệp ở bình minh công nghiệp 4.0 [Journal of Risk and Financial Management - ISI Web of Science]
}

Hồ Mạnh Toàn

AISDL

Hà Nội, 17-03-2019

Công nghiệp 4.0 đang thay đổi cuộc sống của hàng tỉ người trên thế giới. Những người khởi nghiệp có lẽ hiểu rõ hơn hết sự thay đổi này khi mà rất nhiều startup công nghệ hiện đang đóng vai trò quan trọng trong mô hình khởi nghiêp điên toán [1] và kinh tế chia sẻ [2] hiện nay. Facebook, Twitter định nghĩa lại truyền thông; Uber, Grab thay đổi cách thức chúng ta di chuyển; hay Airbnb khiến trải nghiệm du lịch trở nên gần gũi hơn bao giờ hết.

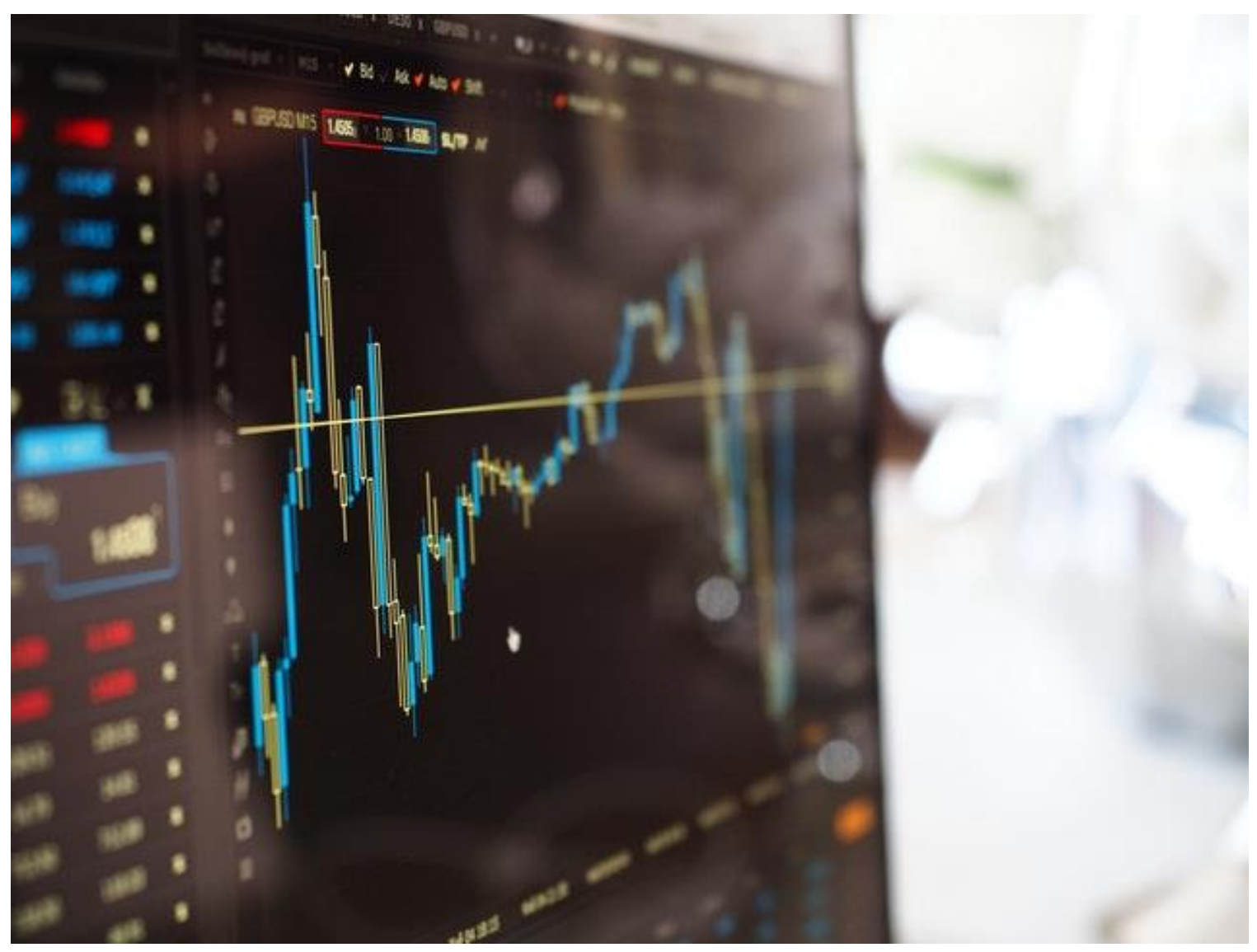

(Nguồn: Photo by rawpixel.com from Pexels)

Cùng với các cơ hội, các dự án khởi nghiệp cũng gặp nhiều thử thách hơn, và cũng phải sáng tạo hơn để đảm bảo nhu cầu về tài chính. Chắc chắn, sẽ không dễ dàng gì để có thể hiểu hết được mọi ngóc ngách của một hoạt động thay đổi theo từng ngày. 
Nhận thấy nhu cầu quan trọng trong nghiên cứu về tài chính khởi nghiệp trong thời đại 4.0, TS. Vương Quân Hoàng (Trung tâm Nghiên cứu Xã hội Liên ngành, Đại học Phenikaa, Hà Nội), với sự hỗ trợ của tạp chí Journal of Risk and Financial Management (ISSN 1911-8074) đã xây dựng số chuyên đề với tên gọi "Entrepreneurial Finance at the Dawn of Industry 4.0".

Tạp chí xuất bản số chuyên đề này là Journal of Risk and Financial Management (ISI Web of Science; Emerging Sources Citation Index), với khả năng cao sẽ có first Impact Factor trong 2 năm tới. Xét trong năm 2019 này, các nhóm tác giả Việt Nam từ nhiều trường đại học khác nhau đã xuất bản 4 nghiên cứu công bố trên tạp chí này $[4,5,6,7]$, điển hình như nghiên cứu mới đây về bất bình đẳng thu nhập do nhóm nghiên cứu thuộc trường Đại học Mở Tp. Hồ Chí Minh thực hiện [4].

Số chuyên đề "Entrepreneurial Finance at the Dawn of Industry 4.0" gửi lời mời các nhà nghiên cứu đóng góp các bài nghiên cứu kết quả mới (original), các bài quan điểm (perspective), thảo luận học thuật (conceptual development), hay các bài tổng quan nghiên cứu (review) về các vấn đề khác nhau trong tài chính khởi nghiệp thời 4.0 nhu: khởi nghiệp điện toán [1], gọi vốn cộng đồng [2], trí tuệ nhân tạo [8], 'không tìm mà thấy' [9].

Các từ khóa quan trọng của số đặc biệt bao gồm:

- $\quad$ Microfinance, crow-funding

- $\quad$ Artificial intelligence (AI) and computational entrepreneurship

- $\quad$ Serendipity as a strategic advantage in entrepreneurial finance

- Governmental policy responses to entrepreneurs' financial needs

- $\quad$ Finance and creative performance in Industry 4.0

- $\quad$ Philanthropic funding, scientific discoveries, and entrepreneurial finance

- $\quad$ Emerging regulatory framework amid the rise of Industry 4.0

- $\quad$ The role of financial markets

- Gender issues in entrepreneurial finance

- Risk management for entrepreneurial finance: tools, techniques, conceptual developments, and limitations 


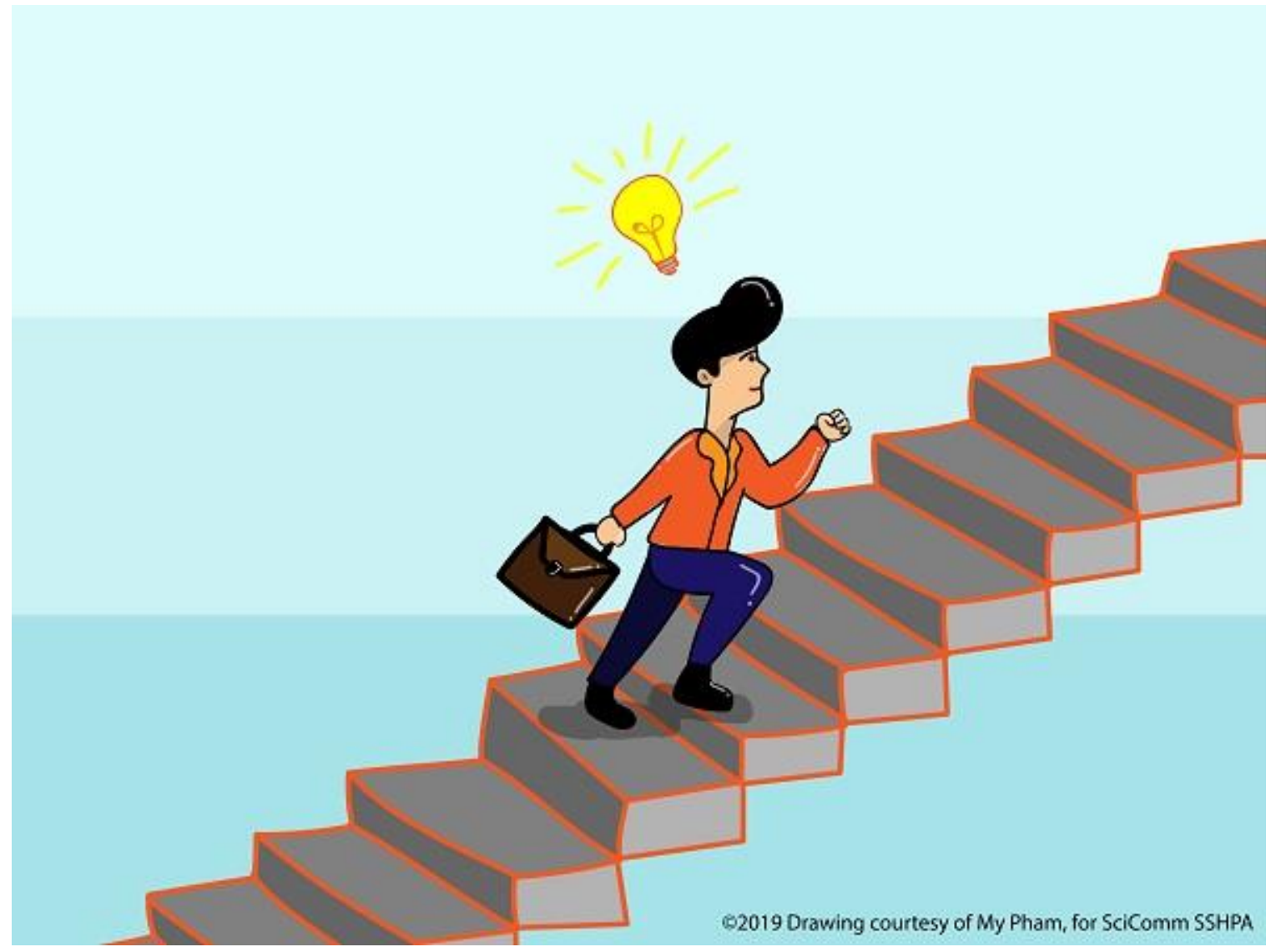

Các nhà nghiên cứu quan tâm có thể gửi thắc mắc trước khi nộp bài đến trợ lí của biên tập là Hồ Mạnh Toàn (Đại học Phenikaa, Hà Nội) qua địa chỉ e-mail: toan.homanh@phenikaa-uni.edu.vn. Mọi thắc mắc sẽ được tận tình giải đáp, với mục đích động viên tỷ lệ đóng góp từ Việt Nam. Với các bản thảo có tiềm năng, đội ngũ trợ lí biên tập sẽ nỗ lực hỗ trợ để giúp có được một bản thảo chất lượng tốt nhất, tăng khả năng xuất bản thành công.

Chúng tôi mong chờ và hân hạnh được phục vụ các tác giả đóng góp.

\section{References:}

[1] Vuong, Q. H. (2019). Computational Entrepreneurship: from Economic Complexities to Interdisciplinary Research. Problems and Perspectives in Management, 17(1), 117-129, DOI: 10.21511/ppm.17(1).2019.11.

[2] Taeihagh, A. (2017). Crowdsourcing, sharing economies and development.Journal of Developing Societies,33(2), 191-222, DOI: $10.1177 / 0169796 \times 17710072$.

[3] Hall, G. (2016). The uberfication of the university. Minneapolis, MN: University of Minnesota Press. 
[4] Vo, H. D., Nguyen, C. T., Tran, N. P., \& Vo, T. A. (2019). What factors affect income inequality and economic growth in middle-income countries?. Journal of Risk and Financial Management, 12(1), 40, DOI: 10.3390/jrfm12010040.

[5] Vo, D. H., \& Zhang, Z. (2019). Exchange rate volatility and disaggregated manufacturing exports: Evidence from an emerging country. Journal of Risk and Financial Management, 12(1), 12, DOI: 10.3390/irfm12010012.

[6] Thuy, V., \& Thuy, D. (2019). The impact of exchange rate volatility on exports in Vietnam: A bounds testing approach.Journal of Risk and Financial Management, 12(1), 6, DOI: 10.3390/irfm12010006.

[7] Vo, D. H., Huynh, S. V., \& Ha, D. T. T. (2019). The importance of the financial derivatives markets to economic development in the world's four major economies. Journal of Risk and Financial Management,12(1), 35, DOI: 10.3390/irfm12010035.

[8] Vuong QH, Ho MT, Vuong TT, La VP, Ho MT, Nghiem PKC, Tran BX, Giang HH, Giang TV, Latkin C, Nguyen HK, Ho CS, Ho RC. (2019). Artificial Intelligence vs. Natural Stupidity: Evaluating AI Readiness for the Vietnamese Medical Information System. Journal of Clinical Medicine, 8(2), 168, DOI: $\underline{\text { https://doi.org/10.3390/icm8020168. }}$

[9] Napier NK, Vuong QH (2013) Serendipity as a strategic advantage?. In Wilkinson (ed) Strategic Management in the 21st Century (Vol. 1: The Operational Environment), pp. 175-199. Westport, CT: Praeger/ABC-Clio. 